but with the virtues (or lack thereof) of pressurized water reactors in general. Most probably, the inquiry will not now begin until the second half of 1982 , implying that construction of the reactor system cannot begin until late in 1983 .

For the electricity undertakings, the chief objective of the proposal to adapt an American design to British circumstances is the hope that pressurized water reactors could be built more quickly than indigenous gas-cooled designs. The Friends of the Earth document, however, is sceptical of the six-year construction time on which the generating board is counting.

Meanwhile, the Central Electricity Generating Board is somewhat encouraged that four of its oldest gas-cooled reactors, shut down some months ago after the discovery of cracks in the expansion joints of the gas-cooling circuits, can soon be started up again. The first of these reactors, at Berkeley on the Severn, is to be restarted in a few months following a demonstration that the cracks have not grown since the reactors were first built

\section{Czech nuclear power}

\section{Action on safety}

Czechoslovakia's nuclear energy authorities have recently made overtures to their British counterparts, suggesting that the agreement on cooperation in nuclear safety, signed almost 15 years ago, should be revitalized. In particular, the Czechs are seeking an exchange of information and expertise on the disposal of nuclear waste and on the training of power station personnel.

The human factor in nuclear accidents has lately become a major concern in Czechoslovaka. Last August, after repeated denials, and without any attempts to prepare public opinion, the authorities suddenly admitted that in the past few years there had been two major accidents at the Jaslovske Bohunice nuclear power station.

During a recent phone-in programme on Prague radio, Dr E. Medke, director of the Nuclear Power Station Research Institute at Jaslovske Bohunice, described the institute's "high quality" research programme, aimed at the "long-term, safe, reliable and in particular, economically effective" operation of Czechoslovakia's nuclear power stations. This, he said, is to include work on the human element in safety. Analysis of nuclear accidents throughout the world, he said, shows that only 20 per cent were caused by equipment failure and the rest by operator error.

A training programme is under way to provide the 1,300 graduate engineers whom the country's nuclear programme will need by 1990 . After taking a first degree in engineering, the candidate will go on to a two-year theoretical course, and then to a power station for practical training. This will include work on a simulator, now being built at Trnava. After careful screening, the student will then become an assistant at a nuclear power station, and will finally take examinations set by the State Commission to qualify for a nuclear engineer's licence.

Czechoslavakia, which is more than selfsufficient in uranium, has a major commitment to nuclear energy, and accordingly tried to hush up the accidents at Jaslovske Bohunice, one of which involved two deaths. But in 1978 the Charter-77 movement published a detailed report on the incidents - and although then still unprepared to acknowledge that anything untoward had occurred, the authorities immediately inaugurated a policy of recruiting nuclear power station workers of a better psychological calibre a major recommendation in the Chartists' report.

In the radio programme, Dr Medke made no mention of the accidents, and left his deputy, Dr S. Novak, to deal with public apprehensions about nuclear power. Regarding the station now under construction at Mochovce near the Hungarian frontier, Dr Novak said that there has never been a case in which one country has contaminated another's territory by nuclear affluent, and that all Czechoslovak power stations have adequate safety measures to prevent environmental damage in the case of breakdown or failure. This statement contradicts the Chartists' report which alleges that in one of the incidents at Jaslovake Bohunice, effluent reached a watercourse. It also contradicts claims from Bulgarian environmentalists that radioactive contaminants can be found in the Danube - although these are conventionially assumed to be of "capitalist" origin.

Vera Rich

\section{Soviet space programme

Mongolia's turn

Last week's spaceflight of the Mongolian cosmonaut, Jugderdemidyn Gurragchaa, coincided with the start of the diamond jubilee celebrations of the Mongolian People's Republic. A few days before the launch, Mongolia's new Five Year Plan was published, extolling the value of science and technology to the development of the republic.

Not surprisingly, most of the experiments performed by Gurragchaa and his Soviet colleagues aboard the Salyut- 6 were aimed at practical applications rather than basic research. One of the major tasks was the mapping of Mongolian natural resources, using conventional cameras and a Bulgarian "Spektr-15" multichannel spectrophotometer. This survey will provide data for existing joint Comecon research projects on Mongolian resources including the irrigation of the Gobi Desert. A programme of simultaneous photo-

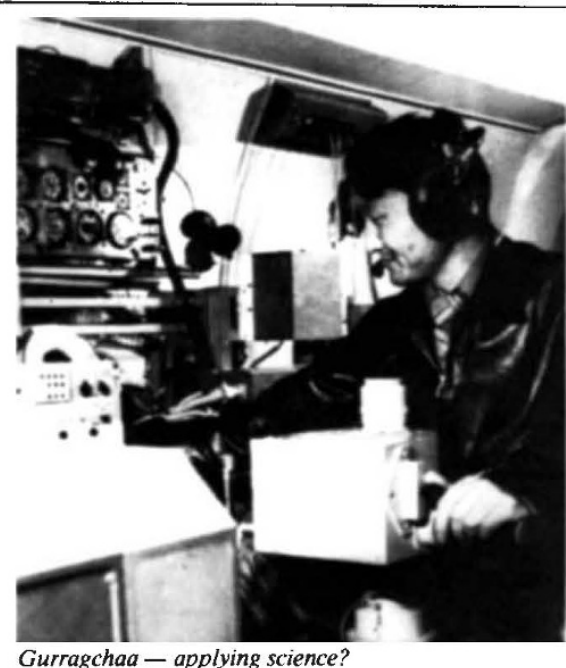

arragchaa - applying science?

graphy of the Salyut spacecraft from Mongolia's two satellite tracking stations (in Ulan Bator and the Gobi) was intended to provide data on factors affecting space geodesy.

The biological programme involved the monitoring of the cosmonauts' biorhythms, work capacity, cardiovascular function and psychological response to the conditions of space travel. The biorhythm observations were started in 1977 during the selection of candidates for cosmonaut training - apparently the first time that a psychological and biochemical study of Mongolian citizens had ever been undertaken on a daily basis. Technological experiments included the study of natural quartz and of various alloys of copper under zero gravity.

Fundamental research was not completely ignored in Gurragchaa's mission. An experiment codenamed in Russian "Izluchenie", (radiation) continued the Mongolian work on primary cosmic rays with energies in the $\mathrm{TeV}$ range which was begun in 1972 with an experiment designed by S. Sugar and B. Chadraa of the Laboratory of High Energy Physics of the Academy's Institute of Physics for the joint Comecon Interkosmos-6 satellite in 1972 . Vera Rich

\section{UK computer industry}

\section{ICL falters}

International Computers Limited (ICL), Britain's largest computer manufacturer, announced last month that it has been trading at a substantial loss since the middle of 1980. The news of ICL's problems came only a few weeks after similar news from Imperial Chemical Industries (ICI). Until the beginning of this year, both companies had been regarded as profitable examples of Britain's otherwise ailing industry.

Unlike ICI, however, ICL is to be bailed out by government money. Sir Keith Joseph, Secretary of State for Industry, has said that the government will act as guarantor for up to $£ 200$ million worth of 
loans which the company is expected to secure from the banks. Help is also to be provided for ICL's research and development programme which last year consumed about 8 per cent of the company's £715 million turnover.

Sir Keith's intervention is seen as a major blow to the Conservative government's policy of not interfering in private industry. But the decision was taken only after several months of searching for private investors had found no takers. The chief justification for supporting ICL when other private industries are allowed to go to the wall seems to be that the smooth operation of many government offices depends heavily on its computers.

ICL is something of a favourite of British governments. When it was created in 1968 from the amalgamation of two computer companies, the government retained a substantial shareholding and supported it heavily during its early years both with cash and with awards of almost all contracts for large computers for government departments. In the 1970s, the company became profitable and in late 1979, Mrs Thatcher's government sold off its shares. But only 18 months later, ICL's profits took a lurch.

Precisely why the company's fortunes changed so suddenly seems to be a mystery. The company itself says that the world recession combined with the strong value of the pound and high interest rates is responsible. There were hints of trouble, it says, in the first half of 1980 but during the second half both home and overseas orders fell off markedly. Others have said that poor management, a concentration on large computers when the market is moving towards desk-top machines, spending too much on parts of the business not connected with manufacturing and even underpricing goods, are also responsible.

Neither the government nor the banks, however, seem to have stipulated conditions for the $£ 200$ million loan. The company hopes to ride out the recession by continuing business much as before and economizing wherever possible. It says, for example, that its research and development programme will continue at much the same level as last year, with the same mix of research on large and small machines. One of the projects on which it pins hopes for the future is the large Distributed Array Processor which has so far been sold to the British National Oil Corporation, for seabed exploration, and Queen Mary College University of London. The Science Research Council is considering buying one for its Rutherford or Daresbury laboratories.

Sir Keith Joseph hopes that the government will not have to make good its guarantee, believing that the loan will see ICL through the recession until business picks up again. Meanwhile, the net is still being cast far and wide in the hope of finding private investment on suitable terms.

Judy Redfearn
London medical schools Mergers galore

The University of London has made a modest beginning on the reorganization of its twelve medical schools. Last week, the senate of the university approved a plan to save something like $£ 5$ million a year, or ten per cent of the present cost to the university of medical education. Some two-thirds of the saving will come from a general reduction of staff-student ratios throughout the medical schools.

The accompanying reorganization of the London medical schools is only a pale shadow of the grand design put forward more than a year ago by a committee under Lord Flowers, rector of Imperial College. At the senate meeting last week, it was formally agreed that the Westminister Hospital Medical School (a clinical school now recruiting about 100 students a year) should be merged with the medical schoo at Charing Cross Hospital (now located in West London). Other proposed groupings of medical schools have been given until later in the year to work out how they will coordinate their teaching.

The Westminster school considers itself unfairly singled out by these developments. Ever since the publication of the Flowers Report, Westminster has been urging the benefits of small medical schools, complaining that its students or their successors will be lost in a medical school with an annual intake of 180 , the planning figure for clinical students at Charing Cross. It also says that the efforts that have been made in the past year or so to coordinate teaching between the two hospitals may be jeopardized by the shotgun marriage now decreed. Given forward commitments to students, it may be as much as five years before teaching comes to an end on the Westminster site.

In retrospect, the schools least affected by the changes now proposed are those at Guy's Hospital and St Thomas's Hospital, which announced last year that they would form a joint school, with a single governing body, but would continue to operate on both the present sites. This arrangement has now been sanctioned by the university senate. The other consortia from which the university is seeking financial savings are University College, Middlesex and St Mary's, which are required between them to save the equivalent of one clinical and one preclinical school; St Bartholomew's and the London Hospital, which have been given until June to suggest how they will merge; and King's College (which has a preclinical school) and King's College Hospital, which seem to be willing to fall in with the recommendation that they should form an integrated unit.

The proposals accepted last week by the senate were recommended by the Joint Planning Committee on Medical Education, set up to pilot the Flowers Report through the university. In the past year, and especially as a result of a detailed analysis of the costs of the London medical schools carried out by a firm of accountants, it became clear that changes of staffstudent ratios offered the most rapid route to cost reductions. The committee accepts as a standard for future staffing a ratio of $1: 10$ for preclinical schools and 1:7 for clinical schools. This would mean the loss of 180 academic posts, which it is hoped can be achieved by natural retirement and wastage in the next five or six years.

Running through the report of the joint committee is the view that medical education should be concentrated in larger units than at present, especially where modern buildings have been provided. In this spirit, the committee recommends that the development of the St George's Hospital site in South London should be continued. The future of the postgraduate medical institutes remains entirely open, however. With the exception of the Institute of Dermatology (which is to merge with St Thomas's Hospital Medical School), the institutes have been seriously affected by the reductions in the past year in the numbers of overseas students. The university is hoping that central government will help bail them out, but no decision has yet been reached.

Last week's decision by the university senate is likely to be regarded, within the University of London, as some kind of precedent for the reorganization of the non-medical parts of the university likely to be recommended by the Swinnerton-Dyer committee, due to report in September, and elsewhere as a sign that, if pressed hard, even British universities can change their ways.

\section{Law of the Sea}

\section{US backtracks}

\section{Washington}

The Reagan Administration's decision to carry out a complete review of the US position on the draft Law of the Sea Treaty, now under discussion at the United Nations in New York, indicates that significant new attitudes may emerge towards international resource disputes ranging from the surface of the Moon to the minerals of the Antarctic continent.

The United States is considering whether to adhere to the concept that natural resources which lie outside the immediate political domain of individual nations should be treated as "the common heritage of mankind" - a term coined by the United Nations - or whether, in the name of free enterprise and the national security implications of a shortage of strategic minerals such as cobalt and manganese, this concept should be abandoned, together with attempts to set up international regulationsto control exploitation.

A new twist to the Law of the Sea negotiations comes from the likely take-over of the Kennecott Corporation, a leading critic 